\title{
Natural Resources and Revenue Sharing in the New Federal System of Nepal: A Proposed Model
}

\author{
Bishnu H. Pandit ${ }^{1}$ and Him L. Shrestha ${ }^{2}$
}

\begin{abstract}
This article considers recent trends in federalism, with particular attention to revenue sharing of natural resources in the new federal system of Nepal. It begins with a general description of the federal system prevailing in other countries, revenue sharing pattern and possible ways that can be implemented in Nepal. The article concludes with an explanation of trends that set the direction for policy innovations in natural resources federalism and general thoughts about the future offederalism in natural resources law in Nepal, which in turn can be reflected in the new constitution. A model consisting of seven provinces based on five criteria (river and hydro-power; forest, wild life and national parks; population/ethnicity; geographic location; and road networks) is also proposed for restructuring new Nepal. Three levels (center, province and local/or community) of new Nepal federal system are proposed. Recommendations are made to be included in the fundamental right and state responsibility part of the constitution.

यस लेखले हाल चलिरहेको नेपालको प्राकृतिक स्रोत र संघीय राज्य व्यवस्था सम्बन्धि वहसलाई चिर्ने कोसिश गरेको छ। यसमा पनि विशेष गरेर प्राकृतिक स्रोतबाट उठेको राजश्व र यसको बाँडफाँड सम्बन्धि सवाललाई समाधान गर्ने सुकाव पेस गर्ने प्रयत्न गरेको छ। शुरुमा यस लेखमा विश्वका अरु विभिन्न मुलुकहरुमा चलिरहेको संघीय व्यवस्था र त्यहाँ भएका आर्थिक अधिकार र राजश्व बाँडफाँड व्यवस्था सम्बन्धि चर्चा गरिएको छ। यस लेखले हाल भइरहेको प्राकृतिक स्रोत र संघिय व्यवस्था सम्बन्धि विषयलाई छलफलमा ल्याई निकट भविष्यमा बन्न गइरहेको नेपालको संविधानमा तत् सम्बन्धि विषयलाई समावेश गर्न नीति निर्माताहरुलाई कक्कक्याउने जमर्को गरेको छ। यस लेखले $७$ वटा प्रान्तहरु भएको नयाँ नेपालको नमुना ढाँचा कोरेको छ। उक्त ढाँचाको लागी $y$ वटा आधारहरु (नदी/जलविद्युत, वन, वन्यजन्तु र राष्ट्रिय निकुज्ज, जनसक्ख्या/जातजाति, भौगोलिक स्थिति र यातायत संजाल) प्रयोग गरिएको थियो। अन्त्यमा मौलिक अधिकार र राज्यको दायित्व सम्बन्धि सवालमा सुकावहरु पेश गरेको छ।
\end{abstract}

Key words: Fedral system, Economic right, Constitution, Revenue sharing, Natural resources management

\section{Introduction}

With the advent of new democratic system in Nepal, after abolition of 240 years old institution of Monarchy, there has been a lot of political debates on as to how the country will be restructured into different federal states or provinces, and how the natural resources are divided across these federal states (Acharya, 2007; Poudel, 2008). Dialogues are being held between various political parties and stakeholders in natural resource management

ICIMOD, Kathmandu, Nepal, Email: bhpandit@ntc.net.np

${ }^{2}$ Kathmandu Forestry College, Kathmandu, Nepal, Email: hlshrestha@gmail.com 
issues and their distributional patterns across various states and local bodies (ICIMOD, 2009-discussion report). Various scholars have given various thoughts regarding integrations of various natural resource management (NRM) components into the over all country's federal plan (Porter, 1998 cited by Poudel 2008). The major impediment in this process is of high-income disparities across various regions, and between ethnic, language and caste groups (Acharya and Sangraula, 2009). These authors argued that this gap could be narrowed by taxing more (additional 46\%) to the high economic classes of people. Therefore the serious question is of how inclusive democracy can be practiced and sustained in long run. In other words, how the new constitution can guarantee the right and access of various castes, language, gender and classes of people to natural resources and also to decision making (Limbu, 2009; Ghale, 2009). Every natural resource has its values in the new federal system structure of Nepal. Poudel (2008) mentioned Eight ' $J a^{\prime}$ Nepali Alphabet - important for Nepal's economic development, and these should be considered equally for developing the federal system of new Nepal. These resources include Jal (water), Jamin (land), Jungle (forest), Jaributi (medicinal plants); Janasakti (human resource), Janawar (animals), Jarajuri (plants) and Jalabayu (climate). Each of these resources is important for any nations for making decision on federal system. Opinion regarding formation of federal state varies across various political parties, scholars, scientists and practitioners. For instance, Gurung (2000) proposed 25 districts against the current 75 districts of Nepal. Neupane (2005) and Sharma (2006) as quoted by Acharya (2007) were in an opinion to make 5 and 6 provinces, respectively. UCPN Maoist party, on the other hand has proposed 9 autonomous regions and 3 sub-regions. Except two regions, all other regions are mostly based on caste and ethnicity. In many discussion forums, some even proposed 3 regions- Gandaki, Koshi and Karnali provinces. Every one has its own logics. The smaller the province, the lesser the administrative costs, but it incurs high transaction costs for the people. It has big implication on revenue sharing. Some scholars recommended to list and to indicate the proportion of revenue to be shared by central, province and local/ community level institutions in the new constitution (Subedi, 2008; Acharya, Kantipur daily, 2009), and some recommended for four levels of federal system including center, province, district and community levels (Pokhrelunpublished paper).

Despite the focus of this paper is not on federal system and structural division, we briefly discuss this issue prior to the section on the revenue sharing between center, provinces and local (community) levels. In this paper, the local level governance includes district, villages and communities. This paper first deals with the definition of federal systems practiced by many countries followed by the ratio of revenue collected, proposed NRM governance in terms of division of federal states, and shared responsibilities between different levels (central, province and local/community). Rather than seeking to capture everything reviewed and discussed during many discussion forums in the process of constitution drafting, in this paper, we highlight major NR related issues raised and revenue sharing system practiced by some of the federal countries. This paper proved to be an exciting initiative for us as it provided us the opportunities to learn and reflect on issues, and then to move forward with renewed 
energy and dynamism for planning Nepal's federal system by the law makers. It is hoped that the recommendations of this paper will provide a basis for the constituent assembly members to plan further on the NRM sector, its revenue sharing mechanism in the upcoming Nepal's new constitution.

\section{Natural resource management $(\mathrm{NRM})$ patterns in different federal countries}

The revenue sharing of natural resources in the new federal system of any countries is a vital component to bring harmony among people living at different levels of governance (i.e. from community to province and central level) (Subedi, 2008). Prior to discussing about natural resources and their revenue sharing, it is important to define 'federalism'. Federalism is a political philosophy in which a group of members are bound together(Latin: foedus, covenant) with a governing representative head. The term 'federalism' is also used to describe a system of the government in which sovereignty is divided between a central governing authority and constituent political units (like states or provinces). Federalism is a system in which the power to govern is shared between national and central (state) governments, creating what is often called a federation and the proponents are often called federalists.

In Europe, "federalist" is sometimes used to describe those who favor stronger federal government, at a national or supranational level, as is the case of the European Union. The term is also used to describe those who favor weaker provincial governments. In the federal nations of Europe (including Germany, Austria and Switzerland) or South America (including Argentina and Brazil), the term "strong federalism" labels situations where sub-national states may have more power than the national (federal) government; it does not imply a strong central government. Some nations with federal systems, such as Switzerland and Canada, are officially confederations, because membership in these countries in the federation is voluntary (Subedi, 2008).

In Canada, federalism implies opposition to sovereigntist movements (usually those of Quebec). The same is historically true in the United States. Advocates of a weaker federal government and stronger state governments are those that generally favor confederation, often related to early "anti-federalists" and later the confederacy. Australia, Brazil and India among others, are also federal countries. Federalism may encompass as few as two or three internal divisions, as is the case in Belgium.

In general, two extremes of federalism can be distinguished. In practice, however, there is always a mixture of both. The revenue sharing pattern across central, provincial and local levels of a dozen of counties is presented in Table 1. With the exception of Nigeria, the developed countries (such as Switzerland, Canada, Germany and USA) receive lesser amount of royalty by the central government compared to developing countries (Table 1). Malaysia has the largest share of revenue (91\%) controlled by central government. The other countries that have more than 60 percent revenue controlled by central government include S. Africa 
(82\%), Australia (76\%), Brazil (68\%), Russia (63\%) and India (61\%). Similarly, Malaysian central government expends largest proportion of the revenue $(90 \%)$ followed by Australia (61\%), Brazil (60\%) and others (Table 1). The analysis of revenue sharing and expenditure pattern shows that the developed countries have had a tendency to hand over largest proportion of revenue to province and local levels despite low level of central collection.

Table 1: Ratio of revenue collected from NR and expenditure by country

\begin{tabular}{|l|c|c|c|c|c|}
\hline \multirow{2}{*}{\begin{tabular}{l}
\multirow{2}{*}{$\begin{array}{l}\text { Name of } \\
\text { Country }\end{array}$} \\
\cline { 2 - 6 }
\end{tabular}} & \multicolumn{2}{|c|}{ Revenue } & \multicolumn{2}{c|}{ Expenditure } & \multirow{2}{*}{$\begin{array}{c}\text { Handover } \\
\text { to P or L }\end{array}$} \\
\hline 1. $\quad$ Australia & 0.76 & 0.24 & 0.61 & 0.39 & 0.20 \\
\hline 2. $\quad$ Brazil & 0.68 & 0.32 & 0.60 & 0.40 & 0.13 \\
\hline 3. $\quad$ Canada & 0.46 & 0.54 & 0.36 & 0.64 & 0.04 \\
\hline 4. $\quad$ Germany & 0.52 & 0.48 & 0.41 & 0.59 & 0.12 \\
\hline 5. $\quad$ India & 0.61 & 0.39 & 0.45 & 0.55 & 0.19 \\
\hline 6. $\quad$ Malaysia & 0.91 & 0.09 & 0.90 & 0.10 & 0.06 \\
\hline 7. $\quad$ Nigeria & 0.48 & 0.52 & 0.46 & 0.54 & 0.05 \\
\hline 8. $\quad$ Russia & 0.63 & 0.37 & 0.47 & 0.53 & 0.08 \\
\hline 9. $\quad$ Spain & 0.53 & 0.47 & 0.51 & 0.49 & 0.26 \\
\hline 10. S. Africa & 0.82 & 0.18 & 0.49 & 0.51 & 0.46 \\
\hline 11. Switzerland & 0.37 & 0.63 & 0.31 & 0.69 & 0.07 \\
\hline 12. USA & 0.55 & 0.45 & 0.46 & 0.54 & 0.11 \\
\hline
\end{tabular}

Source: ICIMOD sharing with CA(constitution assembly) member in April, 2009

Note: $\mathrm{C}=$ central level, $\mathrm{P}=$ Provincial level and $\mathrm{L}=$ Local level

\section{Proposed NRM governance in Nepal: a mix federal system}

The current management of Nepal's natural resources is multi-jurisdictional involving stakeholders from local (village and district) to national level. Informally, some kinds of cooperative arrangements are involved including three spheres of government - national, regional/zonal and local (Subedi, 2008). Under the existing Nepal's Constitution, responsibility for the legislative and administrative framework within which natural resources are managed lies with various departments and ministries, which in turn have traditionally devolved some responsibilities particularly relating to forest management issues to District Forest Offices (DFOs). The matters related to environmental issues such as water and air pollution are dealt by Ministry of Environment, Science, and Technology for fulfilling national environmental 
significance and fulfilling Nepal's owns national and international obligations (such as treaties and conventions).

It has been clearly established through a number of decisions of the natural resource revenue sharing committee of the $\mathrm{CA}$, over the last one year, that the Government has delegated powers to people elected law makers on the use and management of natural resources. The different team of CA members visited people at grassroot level and assessed people's opinion. In practice, however, the final decisions on use of natural resources and revenue sharing will be influenced by different political fractions prevailing in the country. Many of the political parties including UCPN Maoist, CPN (UML) and Nepali Congress are in favor of adopting a more mixed cooperative approach to environmental protection and natural resource management. This approach of federalism has been discussed by law makers basically adopting an initiation and co-ordination role with respect to the development of national policies for natural resource management and environmental protection in recent days. However, some debates on fundamental rights, state responsibilities and principles are ongoing. The issue is more pronounced in land use and distribution. Some parties advocate on land issue such as jasko jot usko pot (those who cultivate land will own the land) as a fundamental right. Some parties remain silent till today on this issue. However, all parties agreed that every citizen should have right to live in fresh air and healthy environment. The country should guarantee some income for the local people on environmental values earned through tree plantation. The equity in revenue sharing across provinces and villages has been common agenda of all parties. Some lawmakers for instance (United Marxist Leninist) proposed for community based federalism (Pokhrel-pers comm.).

\section{Shared responsibilities between different levels}

The shared responsibility between the central, the provincial and local bodies needs to be reflected in the Constitution and latter the agreement should be signed between these three level authorities. The purpose of this agreement is to achieve sound environmental management through a system of parallel and complementary legislation. Under this agreement, consultation between the three levels of governments will be formalized through ministerial councils, standing committees and a range of consultative committees that will also include key industry, scientific and local government representatives. Although particular responsibilities can vary according to the legislative environment and the administrative arrangements within a particular jurisdiction, the traditional division of responsibilities between the levels of government (central, provincial and local) authorities and individual land owners in Nepal for natural resource management are proposed in Table 2. 
Table 2: Division of responsibilities for natural resource management in Nepal

\begin{tabular}{|l|c|c|c|c|}
\hline \multicolumn{1}{|c|}{ Jurisdiction Activities } & Center & Province & $\begin{array}{c}\text { Local/com } \\
\text { munities }\end{array}$ & $\begin{array}{c}\text { Individuals/ } \\
\text { corporations }\end{array}$ \\
\hline $\begin{array}{l}\text { Adherence to international / national } \\
\text { conventions }\end{array}$ & $* * *$ & $* *$ & $*$ & $*$ \\
\hline Leadership and catalyzing change & $* * *$ & $* * *$ & $* * *$ & $*$ \\
\hline $\begin{array}{l}\text { Administer land and water legislation } \\
\text { and regulation }\end{array}$ & $*$ & $* * *$ & $* *$ & - \\
\hline Undertake regional and local planning & $*$ & $* *$ & $* * *$ & $*$ \\
\hline Support for research and development & $* * *$ & $* * *$ & $*$ & - \\
\hline Development of national NRM policy & $* * *$ & $* *$ & $*$ & $*$ \\
\hline $\begin{array}{l}\text { NRM extension and community } \\
\text { capacity building }\end{array}$ & $*$ & $* * *$ & $* *$ & $*$ \\
\hline On-ground management & - & - & $* *$ & $* * *$ \\
\hline
\end{tabular}

All three proposed spheres of government in Nepal (local, province and federal) should be involved in NRM policy initiatives, such initiatives should generally be developed independently of each other in an ad hoc way for the first time. This will lead to a diversity of NRM institutional arrangements existing across these three levels. Not only does each level of government typically adopt its own NRM governance approach but province and federal (central) governments will continue to develop policy as well as design and implement programspecific arrangements that differ in scale, style, resourcing and accountability standards within themselves. These fragmented institutional arrangements may well involve competing objectives and interests.

\section{Natural resource management governance within the proposed federal system}

In view of the above background, the natural resource management governance within Nepal's federal system should involve a simple but 'nested' or polycentric decision-making arrangements (versus neatly hierarchical) being carried out concurrently across a range of political decision-making levels (e.g. central, provincial, local) and horizontally across a fragmented array of territorial and sectoral areas. Ideally, the basis for division of the province or state should follow any of the natural resource jurisdictions. In Nepal, the three big river basins or watersheds (Gandaki, Kosi and Karnali) could be the basis for federal division. The other natural resources such as forest, land, NTFPs, wild life, hydro power, national parks, minerals, wildlife, sand and gravels etc should also be taken into consideration before 


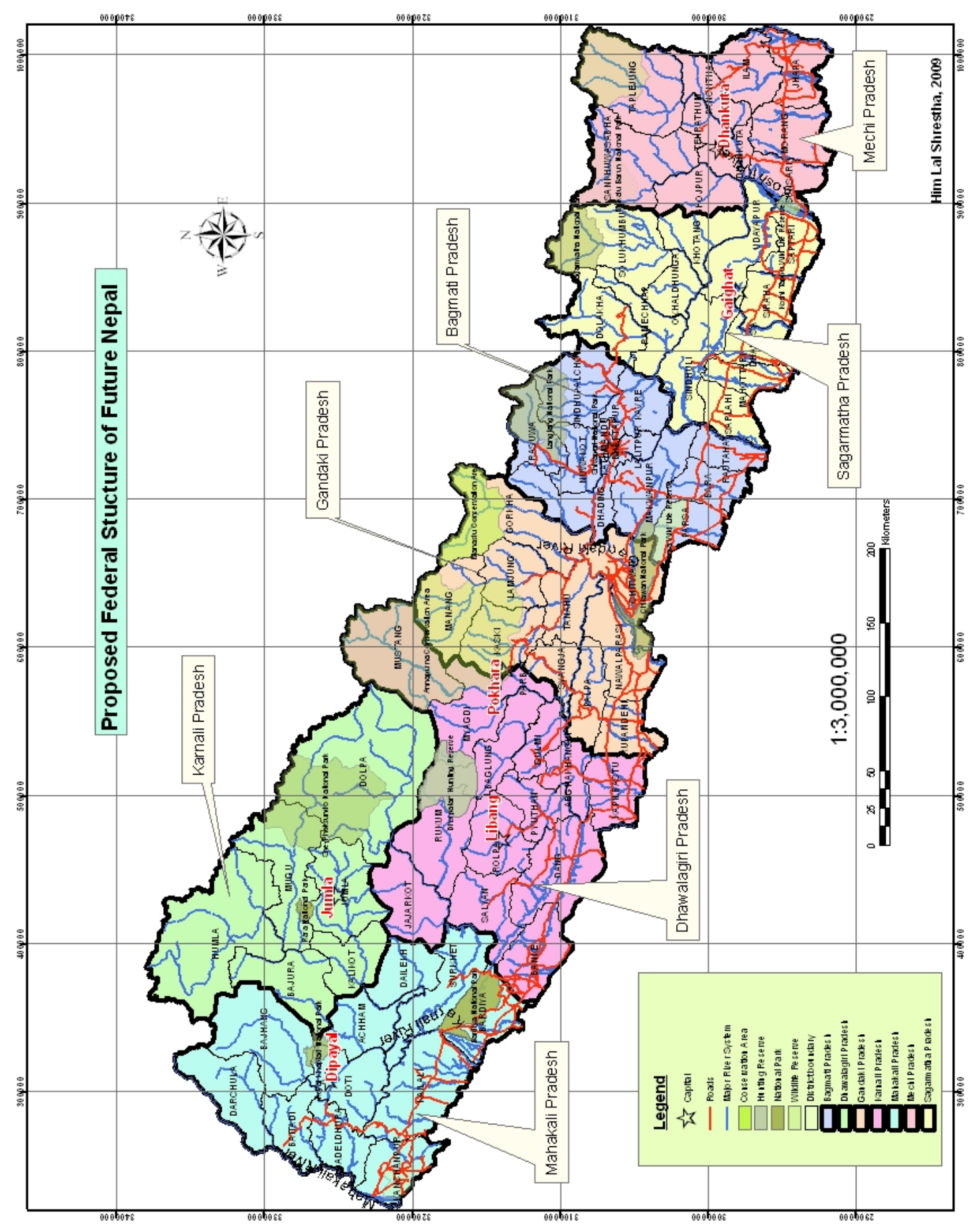

Figure 1: Proposed Federal structure of new Nepal 
making any federal divisions. Besides, physical capital such as road networks, buildings, bridges etc, geographic location, and population (ethnic composition, gender and poverty level) should also be taken into consideration. We need to over lay of all these factors and investigate the best fit among them. In this model, we basically consider five criteria for federal divisions. These include: (i) river and hydro-power; (ii) forest, wild life and national parks; (iii) population/ethnicity; (iv) geographic location; and (v) road networks. Because of the foreseen administrative expenses and complexity involved in the new federal system management, the provinces should not be more than six to seven, and these should be mostly divided vertically leaving access from North to South or vice versa. A total of seven provinces are proposed in the new federal system of Nepal (see Figure 1). These include: (i) Mechi Pradesh, (ii) Sagarmatha Pradesh, (iii) Bagmati Pradesh, (iv) Gandaki Pradesh, (v) Dhawalagiri Pradesh, (vi) Karnali Pradesh and (vii) Mahakali Pradesh.

This system is continually evolving at all political and sectoral levels. For example, each state or province is evolving in different ways, for different reasons, in varying contexts and at different rates in the process of federal system development. At each level of this multilayered and polycentric system, there are different emergent properties and problems (such as heterogeneity in language, caste, geography, poverty and gender) to be addressed. As reflected above, the different levels may be coupled by a diverse range of relationships that involve an iterative process of devolution and feedback of functions and outcomes within and between different decision-making levels (e.g. federal to local and vice versa).

\section{Distribution of natural resource revenue}

Based on the experience of other countries and on-going discussions and sharing with the CA members, civil societies and government bureaucrats, eleven NR revenue items have been identified (Table 3). These include custom duty of any NR products, land revenue, VAT on NR products, water royalty, forest products, wildlife, minerals, hydropower royalty, tourism, earning from hydro-power, and sand and gravel (Table 3). The custom duty of any NR products and royalty on earning from hydro power should be the responsibility of the central (federal) government. Land revenues, forest product royalty and tourism tax should be mostly collected by the local government bodies. This will not only increase the revenue of the country but also bring harmony between tax payers. Tax related to wildlife and national parks, water royalty and minerals should be vested with federal government as they are mostly linked to historical significance and are mostly controlled by international conventions and treaties. Value added tax should also be collected by central government with little scope for province. 
Table 3: Distribution of natural resource royalty in percentage

\begin{tabular}{|c|c|c|c|}
\hline NR Royalty source & Center & Province & Local/community \\
\hline $\begin{array}{l}\text { 1. Custom duty of any } \\
\text { products }\end{array}$ & 100 & - & - \\
\hline 2. Land revenue & 25 & 25 & 50 \\
\hline 3. VAT on NR products & 60 & 40 & \\
\hline 4. Water royalty & 40 & 30 & 30 \\
\hline 5. Forest products & 25 & 25 & 50 \\
\hline $\begin{array}{l}\text { 6. Wildlife and national } \\
\text { parks }\end{array}$ & 33 & 40 & 27 \\
\hline 7. Minerals & 40 & 30 & 30 \\
\hline 8. Hydro-power royalty & 40 & 30 & 30 \\
\hline 9. Tourism & - & 33 & 67 \\
\hline $\begin{array}{l}\text { 10. Earning from } \\
\text { hydropower }\end{array}$ & 100 & - & - \\
\hline 11. Sand and gravel & - & 33 & 67 \\
\hline
\end{tabular}

Source: ICIMOD presentation to CA member in April 2009

\section{Conclusion and Recommendations}

Since natural resources are the important components for economic transformation of new Nepal, they should be considered as one of the main criteria for the political restructuring of Federal Nepal. Class, caste, language, geographic distribution and road networks are other criteria to be considered for the restructuring of Federal Nepal. In view of the regional and economic disparities between and among various caste, gender, language, region and classes of people, the framework for economic rights and revenue sharing should be developed with proper consultations of the various stakeholders and groups prior to final document ready for publication. Failure to include a clear mechanism for revenue sharing between central, province and local levels in the new constitution will bring negative impacts for the nation. Considering this point in mind, we recommend some points to include in the framework of the new constitution.

Preamble: The new constitution should be devoted to conservation of bio-diversity and sustainable use of natural resources. While doing so, the state should also recognize the rights of local people to use natural resources in a sustainable manner.

Fundamental rights: Every citizen should have the right to live in a healthy and clean environment. No people should be dying without food and water. The state should take 
guarantee of the basic needs (food, shelter and cloth). On top of this, indigenous people's rights in use of natural resources should be guaranteed by the state. While doing so, individual rights of other caste and class should not be overlooked. Landless and poor should have equity in right of ownership on the land on which they work. A scientific and pro-poor based land reform act needs to be enacted.

Fundamental duties: Every citizen should take responsibility to conserve and save the natural resources. In order to avoid disparities in income from NR, the richer people should be charged with additional royalties.

State responsibilities, guiding principles and rules: While conserving, protecting and sustainably utilizing NR, the emphasis should be given to equity in distribution of NR among people of disadvantaged groups. Natural resources should not be limited to a few individuals and groups; these should be for the people who have been deprived since ancient time. The state should guarantee the income to be received from environmental goods and services that is incurred from management of natural resources. In other words, if a person grows trees, shrubs and herbs (perennial) in degraded land, he or she should be compensated for his/her work (from India's constitution). Those who plant trees on hill should own the resources produced from that hill (from China's constitution).

Provision for a natural resource commission at national level: Despite above provisions, some time the issue related to equity in distribution of natural resources does not apply. This commission if formed will take overall responsibility to make these things happen in practice. In order to avoid disparities between rich and poor, the high economic class people (rich) should be charged additional taxes on the natural resources. This could be done after wellbeing ranking is conducted.

Ownership towards natural resources: Every citizen, community and province should have ownership towards their natural resources. In absence of this, whatever mentioned earlier will not be applied.

Natural resources issues in state restructuring: All seven provinces proposed in this paper are not equally endowed with natural resources. These vary from one province to another and one district/or community to another. Despite this variation, the state should develop a mechanism to share and transport resources from high resource zone to low resource zone without any hastle.

\section{Reference}

Acharya, R. C. 2007. A Model for Political Restructuring and Electoral System of Federal Nepal: Building on the Strength of Ethnic Diversities and Regional Complementarities. Ottawa, Canada. 
Acharya, R. and Sangraula 2009. Income Disparities and Poverty in Nepal: Regional and Ethnic Dimensions. World Bank.

Ghale, K. 2009 (066). Samudaya Kendrit byabasthapanko Khancho (The need for community focused management) Kantipur National Daily Newspaper May 212009, Kathmandu.

ICIMOD, 2009 (unpublished). "Discussion paper presented to Constituent Assembly Members on April-13-14, 2009". International Center for Integrated Mountain Development Kathmandu

Kantipur Daily, 2009 (066). Janatako Awaj (Voices of People). Kathmandu.

Limbu, S. 2009 (066). Prakritik srotma samudayako adhikar (Community Rights on Natural Resources) Kantipur National Daily Newspaper- May 21-2009, Kathmandu.

Poudel, D. D. 2008. Management of Eight ' $J a^{\prime}$ for economic development of Nepal. Journal of Comparative International Management, 11 (1): 15-27. University of Louisiana. USA.

Pokhrel, A. P. 2009- (pers. comm.). Personnel communication and suggestion obtained from written notes.

Subedi, S. 2008 (065). Nepalma sanghiyata ra karya jimbedari nirdharan (Federal System in Nepal and division of work responsibility. United Graphic Printers Pvt., Kathmandu. 